\title{
Potencial of different hydroxyapatites as biomaterials in the bone remodeling ${ }^{1}$
}

Pedro Carvalho Cassino', Larissa Schimidt Rosseti", Osmar Ignácio Ayala"', Marco Antônio Utrera Martines ${ }^{\prime \prime \prime}$, Luciane Candeloro Portugual'v, Claudio Goncalves de Oliveira'v, landara Schettert Silva ${ }^{\mathrm{V}}$, Ruy de Araujo Caldas ${ }^{\mathrm{VI}}$

'Fellow PhD degree, Postgraduate Program in Health and Development, Universidade Federal do Mato Grosso do Sul (UFMS), Campo Grande-MS, Brazil. Conception and design of the study, acquisition and interpretation of data, manuscript preparation.

"Fellow Master degree, Postgraduate Program in Health and Development, UFMS, Campo Grande-MS, Brazil. Veterinary assistance in the experimental study.

I'PhD, Associate Professor, Department of Biological and Health Sciences. UFMS, Campo Grande-MS, Brazil. Statistical analysis, histopathological examinations.

IVPhD, Associate Professor, Chemistry Institute. UFMS, Campo Grande-MS, Brazil. Technical procedures.

${ }^{\mathrm{V}} \mathrm{PhD}$, Associate Professor, Postgraduate Program in Health and Development in the Midwest Region, UFMS, Campo Grande-MS, Brazil. Conception and design of the study.

V'Senior Visiting Professor, Postgraduate Program in Health and Development in the Midwest Region, UFMS, Campo Grande-MS, Brazil. English language, manuscript writing.

\section{Abstract}

Purpose: To analyze the therapeutic potentials of different hydroxyapatites used for the correction of bone defects in rats.

Methods: Forty rats, male, albino wistar, were distributed in 4 groups. They were submitted to a $3.5 \mathrm{~mm}$ defect in tibia. They received low purity hydroxyapatite, Strontium hydroxyapatite and hydroxyapatite doped with gallium, having a seven day evaluation time. Histopathology slides were stained with hematoxylin-eosin, for morphological evaluation. Were analyzed inflammatory processes, necrosis, presence of osteoclasts and osteoblasts, presence of the material, presence of white cells, neovascularization and bone neoformation.

Results: It was observed that the groups HAPSr and HAPGa, presented better results of trabecular bone, hyaline cartilage and bone marrow more organized.

Conclusion: There was improvement in the repair of the bone defect produced, showing that these hydroxyapatites are effective osteoinductive, osteoconductive, osteintegrant agents and have biocompatibility, and may be indicated for use in defect repairs.

Key words: Biocompatible Materials. Durapatite. Strontium. Bone Remodeling. Rats. 


\section{Introduction}

Synthetic hydroxiapatita has been a study because of its properties of biocompatibility, osteoconduction and osseointegration ${ }^{1}$, which increases its similarity with tissue, making it a substitute for bone, such as implant grafting ${ }^{2}$.

By their structure, calcium ions can be replaced by metals with compatible ionic rays such as lead, cadmium, copper, zinc, strontium, iron, among others. In this way individual substitution compounds or solid solutions can be obtained as viable alternatives with the use of additives which stimulate osteosynthesis ${ }^{3}$.

Strontium is a bone trace element with double effects on metabolism, being described that it acts to promote proliferation and differentiation of osteoprogenitor cells, but with an inhibitory effect on the terminal differentiation of osteoclasts ${ }^{4}$. In addition to presenting these properties, strontium, by its incorporation improves the osteoinductivity of different bone implants, such as titanium alloys, bioactive glasses and ceramics ${ }^{5}$.

Low doses can promote the synthesis and formation of osteoid tissue, aiding bone growth and metabolism. They are currently used clinically to promote osteoid formation and treat osteoporosis ${ }^{6}$.

Strontium has had its improved form to increase the proliferation of osteoblasts, promote the formation of new bone and osseointegration and also prevent bone dissolution. It is an indicated addition to improve the bioavailability and the bone induction of hydroxyapatite, and studies indicate that when replacing the calcium ion with strontium ion in hydroxyapatite, it alters the description of this but improves the mechanics of crystal growth ${ }^{7}$.

Both forms of apatite of calcium phosphates and strontium closely resemble the mineral structure of bone and dental tissue which, in its physiological state, comprises hexagonal $\mathrm{Ca}(\mathrm{Sr}) 10$ (PO4)6 $(\mathrm{OH}) 2$ prisms, this being similarity that facilitates an easier integration with the mineral components of bone and teeth ${ }^{3}$. In particular, strontium hydroxyapatite (HAPRS) is a viable alternative for osteoporosis and offers structural integrity in fractures associated with bone demineralization ${ }^{8}$.

Gallium has anabolic properties in bone tissue, where formation and remodeling processes can interfere with bone resorption through inhibition of osteoclast activity. In this sense it can be used in the treatment of resorptive diseases, reducing accelerated bone loss in patients with cancer and metabolic bone disease. The concept of using certain therapeutic measures as adjuvants to the traditional anticancer treatment to strengthen the bone tissue against erosion due to metastases $^{9,10}$.

In addition to acting directly on osteoclasts, gallium may inhibit bone formation and resorption stimulated through action on osteoblasts ${ }^{10}$. Evidence from in vivo studies to improve bone formation suggests that it is due to marked bone formation and increased bone calcium content in rats treated with gallium nitrate ${ }^{9}$.

Therefore, any process that allows an increase of the bone response, preservation of the adjacent tissue, less tissue reaction, allows a fast response of the organism to injury and shorter recovery time with fast return to activities.

\section{- Methods}

The study was approved by the Animals Research Ethics Committee of UFMS (protocol CEUA/UFMS number 723/2015) and was performed in accordance with the International Guiding Principles for Biomedical Research Involving Animals, published by the Council for International Organizations of Medical Sciences (CIOMS), as well as with the Brazilian law on the scientific use of animals (Law 11794/2008). 
Adult male Wistar rats 90 days old, weighing 260-350 grams, were obtained from the Central Laboratory for animals UFMS, and randomized into three groups: $\mathrm{G} 1, \mathrm{n}=10$, with low purity hydroxyapatite (HAP) and $G 2, n=10$ with strontium doped hydroxyapatite (HAPSr), and $G 3, n=10$ with hydroxyapatite doped with gallium (HAPGa). They were observed by 7 days. The animals were housed in a polypropylene cage with containing paddy husk as bedding.

All animals were kept in ventilated rack and maintained at controlled conditions of temperature $\left(23 \pm 1^{\circ} \mathrm{C}\right)$, humidity .and dark-light cycle (12 hours). The animals had free access to standard pellet (Nuvilab) and water ad libitum.

For the preparation of HAPSr the starting materials used were di-ammonium hydrogenphosphate $\quad\left(\begin{array}{llll}\left.\mathrm{NH}_{4}\right) & 2 \mathrm{HPO}_{4} & \text { and }\end{array}\right.$ octahydrate strontium hydroxide octahydrate $\mathrm{Sr}(\mathrm{OH})_{2} 8 \mathrm{H}_{2} \mathrm{O}$, both of analytical grade purity purchased from Merck and Sigma-Aldrich, respectively. Synthesis, on a $10 \mathrm{~g}$ scale, of strontium hydroxyapatite was made with hydrated hydroxyapatite containing strontium and was prepared by means of a reaction ${ }^{3}$.

To obtain the low purity hydroxyapatite a calcium hydroxide solution was obtained which was prepared using $18.52 \mathrm{~g}$ of $\mathrm{Ca}(\mathrm{OH})_{2}$ in $500 \mathrm{ml}$ of distilled water. $10 \mathrm{~mL}$ of phosphoric acid in $300 \mathrm{~mL}$ of distilled water was diluted. At a rate of two drops per second at $40^{\circ} \mathrm{C}$ at $\mathrm{pH}=7.5$, held constant by the addition of ammonium hydroxide. Then the material obtained was washed with distilled water and $1 \mathrm{mmol} / \mathrm{l}$ of phosphoric acid was added thereto, this solution was aged overnight. The synthesized powder was calcined at $700^{\circ} \mathrm{C}$. These volumes correspond to a ratio of $5: 3$ between $\mathrm{Ca}(\mathrm{OH})_{2}$ and $\mathrm{H}_{2} \mathrm{PO}_{3}$.

The HAPGa was obtained by the preparation of gallium doped hydroxyapatite by Instituto de Química (INQUI - UFMS), using gallium salt according to the scheme in 100 $\mathrm{ml}$ of distilled water, $41.37 \mathrm{~g}$ of $\mathrm{Ca}\left(\mathrm{NO}_{3}\right)_{2} 4 \mathrm{H}_{2} \mathrm{O}$ (solution 1). In $50 \mathrm{ml}$ of distilled water, $0.26 \mathrm{~g}$
$\mathrm{Ga}\left(\mathrm{NO}_{3}\right)_{3} \times \mathrm{H}_{2} \mathrm{O}$ (solution 2) was dissolved. In $75 \mathrm{ml}$ of distilled water were dissolved $9.90 \mathrm{~g}$ of $\left(\mathrm{NH}_{4}\right)_{2} \mathrm{HPO}_{2}$ (solution 3 ). Since it was previously established that the coefficient $x$ of the hydrate $\mathrm{Ga}\left(\mathrm{NO}_{3}\right)_{3} \times \mathrm{H}_{2} \mathrm{O}$, corresponds to $\sim 6$.

After this step, solution 1 and 2 were mixed, obtaining a volume of $100 \mathrm{ml}$ (solution 4 ), then mixing solutions 3 and 4 rapidly forming a voluminous colloidal mass immediately (solution 5).

The white colloidal mass (solution 5) was added ammonium hydroxide to $\mathrm{pH}$ between ${ }^{10,11}$. The $\mathrm{NH}_{4} \mathrm{OH}$ solution was dripped from a burette, and a total of approximately $4 \mathrm{ml}$ was consumed. This solution (5) was heated under stirring for 2 hours at $40^{\circ} \mathrm{C}$, then allowed to stand for 20 hours to allow for better crystallization. The crystalline precipitate accumulated at the bottom leaving a clear supernatant.

This solution was again heated under stirring at 95 for 3 hours. The precipitate was separated by vacuum filtration and washed five times. The precipitate was placed in a desiccator which contained approximately $20 \mathrm{ml}$ of liquid nitrogen to avoid contact with $\mathrm{CO}_{2}$ of the ambient air, thus preventing the undesired formation of apatite carbonate.

After 24 hours in the desiccator a $\mathrm{P}_{2} \mathrm{O}_{5}$ capsule was introduced in order to dehydrate the material. The capsule was replaced with another containing fresh $\mathrm{P}_{2} \mathrm{O}_{5}$ to complete the drying process at room temperature.

At the end of the batching process the material was allowed to dry in an oven at $60^{\circ} \mathrm{C}$ until the constant mass was obtained, after which the material was heated at $1100^{\circ} \mathrm{C}$ for 3 hours.

Once the material to be used as a bone substitute was obtained, $10 \%$ ketamine hydrochloride induced anesthetic level was administered at a dose of $0.25 \mathrm{mg} / 100 \mathrm{~g}$ administered intraperitoneally in combination with $2 \%$ xylazine hydrochloride at a dose of 0 , 1 to $0.3 \mathrm{mg} / 100 \mathrm{~g}$, and is calculated individually according to the weight of each animal.

Under aseptic technique, the skin was 
incised on the cranial-medial surface of the tibia of approximately $1 \mathrm{~cm}$, to make the bone defect.

After access to the bone, the drilling process was carried out with the help of a DREMEL $^{\circ} 3000$ Micro-generator with $120 \mathrm{~W}$ at 33000 revolutions per minute, equipped with a DREMEL ${ }^{\circ}$ Model 191 drill bit with $3.5 \mathrm{~mm}$. material on the animals drawn. The produced bone defect extended from the periosteum to the medullary canal, only one member of each animal was operated (Figure 1).

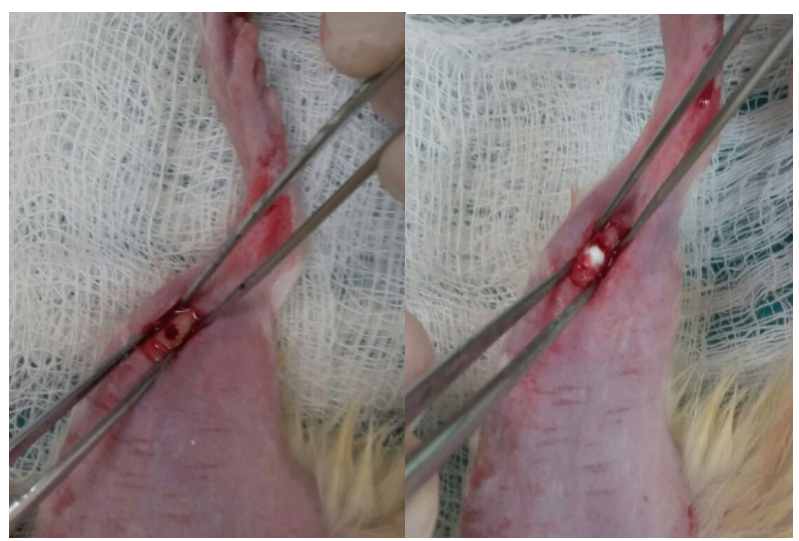

Figure 1 - Bone defect produced with application of the material, in quantity needed to fill the bone defect.

After defect preparation and hemostasis, the material (HAP, HAPGa or HAPSr) was applied in a quantity necessary to completely fill the bone defect, the synthesis was by simple skin suture (nylon 4-0), the animals were observed for a period of twelve hours when they received $0.1 \mathrm{ml} /$ animal of antiinflammatory (Flunixin-Meglunine, Banamine ${ }^{\circ}$, Shering-Plow) intramuscularly.

Seven postoperative days, euthanasia was performed with a lethal dose of Thiopental Sodium $100 \mathrm{mg} / \mathrm{kg}$ intraperitoneally. After collection of the tibias, the implants were accessed through the incision created in the previous surgical intervention. The obtained bones were adequately identified and evaluated for macroscopic appearance and packed in vials containing $10 \%$ formaldehyde.
Histopathology slides were stained with hematoxylin-eosin in order to evaluate the morphological and cellular characteristics of each animal, checking inflammatory processes, areas of necrosis, presence of osteoclasts and osteoblasts, presence of the material, presence of white cells, neovascularization, and neoformation.

\section{- Results}

The histological analysis revealed that in the control group there was presence of primary bone with thickness that varied from thin to thick, presenting bone trabeculae with rows of pavement osteoblasts and no osteoclasts were observed, which shows that this tissue was not under bone remodeling. No foreign body giant cells were observed, which is consistent, since no biomaterial graft was used. The connective tissue associated with the bone tissue (outside the edges of the lesion area) was less cellular, indicating a lower degree of tissue remodeling. In the central region of the medullary canal, small areas of primary bone tissue (trabecular bone) mixed with the bone marrow can be observed in some samples of the same group, whereas in other samples only red bone marrow was observed inside the spinal canal.

In the groups: HAP, HAPSr and HAPGa a thicker layer of primary (trabecular) bone was observed around the secondary bone. In this region of trabecular bone, there was presence of cubic and columnar osteoblasts, in addition to osteoclast, which indicates neoformation with bone remodeling. Giant cells of the foreign body surrounded by an amorphous material were exposed, and in relation to the connective tissue around the bone (outside the edges of the lesion), the HAP and HAPGa groups showed to be very cellular, indicating intense tissue remodeling. In the HAPSr group, no cellular tissue was observed. In the HAP and HAPGa groups, the interior of the medullary canal was 
filled with enough primary (trabecular) bone tissue between bone marrow cells. In the SR group, the spinal canal had less primary bone and more organized bone marrow (Figure 2).

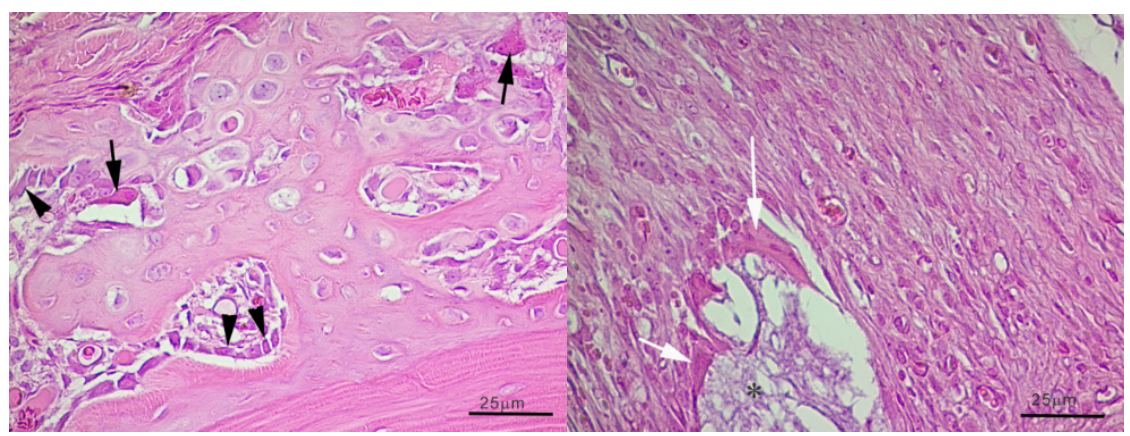

Figure 2 - Control increase in objective of $x 40$ - Large-magnified image of primary bone of the control group. Inactive osteoblasts (thin arrows) and active osteoblasts (arrowheads). Group Hydroxyapatite of Sr increase in objective of $x 40$ - giant cells. Image of connective tissue in process of remodeling. Giant foreign body cells (white arrows); strontium in the process of resorption $(*)$.

In addition to the observed secondary trabecular bone, in the HAPGa and HAPSr groups, a large area of hyaline cartilage associated with the trabecular bone was observed, which indicates the great possibility of endochondral ossification, since it has many chondrocytes proliferating and producing cartilaginous matrix, so that more trabecular bone formation can occur on top of the cartilaginous matrix, which suggests that in these treatments there may be a greater bone remodeling by endochondral ossification in relation to the other groups.

Measurements of the largest area of the bone callus were tabulated for further measurement and comparison, and the length of the primary bone area $(\mathrm{mm})$ in the control group was $15.13 \mathrm{~mm}$, in the group that received the low purity hydroxyapatite obtained a value of $49.55 \mathrm{~mm}$, animals treated with HAPSr values were $36.83 \mathrm{~mm}$ and in the HAPG group the bone length in $\mathrm{mm}$ was 48.74 $\mathrm{mm}$. After confirming the normality of the data by the Kolmogorov-Smirnov test, the ANOVA variance test of one criterion was applied to verify if there were statistical difference and the Tukey test. It was found that between the control and treated groups, $p<0.01$, and among the groups that received the materials, $\mathrm{p}<0.05$ (Table 1).

Table 1 - Measured values in $\mathrm{mm}$, of the largest area of the bone callus between groups.

\begin{tabular}{lccc} 
& \multicolumn{1}{c}{ Control } & HAP & HAPSr \\
\hline $\begin{array}{l}\text { Length of primary } \\
\text { bone area }(\mathrm{mm}) .\end{array}$ & $15.13 \pm 97.39^{\mathrm{a}}$ & $49.55 \pm 19.60^{\mathrm{b}, \mathrm{c}}$ & $36.83 \pm 12.23^{\mathrm{b}, \mathrm{c}}$ \\
\hline
\end{tabular}

*Distinct letters compared between columns present a statistically significant difference (a, b means $p<0.01$ ), (c means $p<0.05)$.

\section{- Discussion}

The effects of strontium ranelate at different doses $(125,250,650 \mathrm{ml} / \mathrm{kg} /$ day) did not cause adverse effects, being considered safe and well tolerated, and strontium prevented ovariectomy-induced deterioration in rats when submitted the mechanical stress the energy needed for the fracture to occur was higher than in the control group and he observed a greater number of trabeculae and less trabecular separation in these animals ${ }^{11}$.

The effect of strontium doped nanohydroxyapatite on sheep bone defects, 
this material promotes bone neoformation in the periphery to the center of the defect, besides the presence of loose connective tissue in the central portion of the defect, little inflammatory infiltrate and a large amount of biomaterial in the periphery bone matrix ${ }^{12}$.

Biocompatibility, osteogenesis, and in vivo (rabbit) degradation of porous strontium doped polyphosphate scaffolds, analyzed by histopathology and $x$-ray, indicate that the material shows good compatibility and osteoconductivity, observing higher bone formation, collagen type 1 and morphogenic proteins, considering this mineral of orthopedic interest ${ }^{13}$.

The effects of doping of different minerals ( $\mathrm{K}, \mathrm{Na}, \mathrm{Mg}, \mathrm{Zn}$ and $\mathrm{Sr}$ ) on calcium polyphosphate show that this compound, when associated with $\mathrm{Sr}$, presents slower degradation when exposed to body fluids. Mineral release and gradual and provides adequate osseointegration and biocompatibility ${ }^{14}$.

The topical application of strontium chloride concluded that this material stimulates and accelerates bone neoformation in surgical defects treated with strontium chloride (28 days) when compared to untreated. At 28 days, there is presence of bone neoformation, being predominantly primary. At 56 days, the new bone formation completely filled the surgical defects, both in the group where the physiological solution was used and in the group treated with strontium chloride. However, it was observed that in rabbits treated with strontium, the newly developed bone tissue was more developed, showing the presence of Havers systems ${ }^{15}$.

Evaluation of peri-implant bone repair in rats subjected to ovariectomy and treated with Strontium Ranelate, analyzing the linear extent of bone/implant contact, neoformed bone area and osteopontin protein (responsible for the initiation of bone tissue mineralization), these values when analyzed in animals that received strontium were high, allowing an improvement in the osseointegration response ${ }^{16}$.

In estrogen-dependent rats, strontium ranelate $(650 \mathrm{mg} / \mathrm{kg} /$ day) produces greater bone neoformation, better alveolar bone dynamics, greater amount of new bone and trabeculae thickness, when compared to group without medication use ${ }^{17}$.

The synthetic hydroxyapatite as a bone substitute in experimental defects provoked in the proximal third of tibia of dogs, after the application of the material and with periods of observation of 8, 30, 60, 120 days, having its evaluation by electron microscopy, it is considered that the hydroxyapatite propitiated increases the multinucleated cells, osteoclasts and the interaction of mineral granules in concomitance with the neoformed bone, indicating osteointegration and onsteoinduction $^{18}$.

Comparison between porous coral hydroxyapatite and autogenous bone graft in rabbits at intervals of 14, 28 and 90 days, evaluated the clinical, macroscopic, radiological and histopathological parameters, where, although the materials studied are similar, hydroxyapatite is an adequate bone substitute ${ }^{19}$.

The effects of nanohydroxyapatite on sheep bone defects in the histopathological analysis observed bone neoformation in the periphery towards the center, presence of trabeculae, osteoblastic paving, loose connective tissue, presence of the biomaterial and little inflammatory infiltrate, hydroxyapatite presents biocompatible and osteoinductive potential, being indicated for bone replacement ${ }^{12}$.

The process of osteointegration of hydroxyapatite in the alveolar process of the mandible of dogs with defects of $6 \times 5 \mathrm{~mm}$ in the vestibular surface with exposure of the root of the fourth premolar, with observation of 21 , $42,60,90$ and 120 days, had the inflammation in the treated group was lower than in the control group, with acceleration of the filling 
of the defect triggering inflammation and gingival hemorrhage, without compromising its indication ${ }^{20}$.

Tibia of rats with bilateral defects, one of them being filled with hydroxyapatite and after 20, 30 and 45 days of observation, hydroxyapatite was biocompatible in the direct contact with the bone tissue, with evolution in the process of bone neoformation, but there was no acceleration of this process against this material in comparison with the control group, and in no period, in the two groups analyzed, an inflammatory reaction ${ }^{21}$.

\section{Conclusions}

PAH is a biocompatible crystal that has been used in biomedicine as a restorative and is also used in orthopedics, dentistry and ophthalmology.

There is no change in tissue repair behavior, although they are compatible, however, more careful research is needed to elucidate the best mechanisms for obtaining and combining with other elements.

The HAPSR crystal needs no further studies since its preparation is based on a single technique and there may be other ways of replacing the calcium ion.

\section{References}

1. Fu LH, Qi C, Liu YJ, Cao WT Ma MG. Sonochemical synthesis of cellulose/ hydroxyapatite nanocomposites and their application in protein adsorption. Sci Rep. 2018;29:8292-8. doi: 10.1038/s41598-01825566-7.

2. Costantino PD, Friedman $C D$, Jones $K$, Chow LC, Pelzer HJ, Sisson GA. Hydroxyapatite cement. I. Basic chemistry and histologic properties. Arch Otolaryngol Head Neck Surg. 1991;117:379-84. PMID: 1848766.

3. Melnikov P, Goncalves RV. Preparation and characterization of strontium hydroxyapatite $\mathrm{Sr} 10(\mathrm{PO} 4) 6(\mathrm{OH}) 2 \cdot 10 \mathrm{H} 2 \mathrm{O}$ suitable for orthopedic applications.
Materials Latters. 2015;150:89-2. doi: 10.1016/j.matlet.2015.02.110.

4. Huang YZ, Wang JJ, Huang YC, Wu CG, Zhang Y, Zhang CL, Bai L5, Xie HQ1, Li ZY6, Deng L. Organic composite-mediated surface coating of human acellular bone matrix with strontium. Mater Sci Eng C Mater Biol Appl. 2018;1:12-20. doi: 10.1016/j. msec.2017.11.0026.

5. Li Y, Li Q, Zhu S, Luo E, Li J, Feng G, Liao Y, $\mathrm{Hu}$ J. The effect of strontium-substituted hydroxyapatite coating on implant fixation in ovariectomized rats. Biomaterials. 2010;31:9006-14. doi: 10.1016/j. biomaterials.2010.07.112.

6. Aaron JS, Mostafaei F, Lin Y, Xu J. Nie LH. Measurements of strontium levels in human boneinvivo usingportableX-rayFluorescence (XRF). Appl Spectrosc. 2017;71:1962-8. doi: 10.1177/0003702817694383.

7. Ge M, Ge K, Gao F, Yan W, Liu H, Xue L, , Jin $\mathrm{Y}$, Ma H, Zhang J. Biomimetic mineralized strontium-doped hydroxyapatite on porous poly(I-lactic acid) scaffolds for bone defect repair. Int J Nanomedicine. 2018;13:170721. doi: $10.2147 /$ IJN.S147969.

8. Raucci MG, Giugliano D, Alvarez-Perez MA, Ambrosio L. Effects on growth and osteogenic differentiation of mesenchymal stem cells by the strontium-added sol-gel hydroxyapatite gel materials. J Mater Sci Mater Med. 2015;26:90. doi: 10.1007/ s10856-015-5436-0.

9. Melnikov P, Malzac A, Coelho MB. Gallium and bone pathology. Acta Ortop Bras. 2008;16:54-7. doi: 10.1590/S141378522008000100011.

10.Warrel RP, Lovett D, Dilmanuan FA, Schneider R, Heelan RT. Low-dose gallium nitrate for prevention of osteolysis in myeloma: result of a pilot randomized study. J Clin Oncol. 1993;11:2443-50. doi: 10.1200/JCO.1993.11.12.2443.

11.Bain SD, Jerome C, Shen V, Dupin-Roger I, Ammann $P$. Strontium ranelate improves bone strength in ovariectomized rat by positively influencing bone resistance determinants. Osteoporos Int. 2009;20:65364. doi: 10.1007/s00198-008-0815-8.

12. Machado CPG, Pintor AVB, Gress MAKA, Rossi AM, Granjeiro JM, Maia MDC. Avaliação da hidroxiapatita contendo estrôncio como substituto ósseo em tíbias de ovelhas. Innov 
Implant J Biomater Esthet (Impr.) 2010;5:914.

13.Tian $M$, Chen F, Song W, Song Y, Chen Y, Wan $C$, et al. In vivo study of porous strontiumdoped calcium polyphosphate scaffolds for bone substitute applications. J Mater Sci Mater Med. 2009;20:1505-12. doi: 10.1007/ s10856-009-3713-5.

14.Song $\mathrm{W}$, Tian $\mathrm{M}$, Chen F, Tian Y, Wan C, $\mathrm{Yu} \mathrm{X}$. The study on the degradation and mineralization mechanism of ion-doped calcium polyphosphate in vitro. J Biomed Mater B Appl Biomater. 2009;89:430-8. doi: 10.1002/jbm.b.31230.

15.Faria MA, Villa N, Carbonel AAF, Simões RS, Hadad S, Faraco FN. Analise histológica da lesão óssea de mandíbula de coelho após a aplicação local de cloreto de estrôncio. Rev Gaúcha Odontol. 2009;58:1-4.

16.Yogui FC, Coléte JZ, Batista FRS, Momesso GAC, Gomes-Ferreira PHS. Faverani LP, Okamoto R. Avaliação do reparo ósseo periimplantar em ratas com deficiência de estrógeno e tratadas com ranelato de estrôncio. Arch Health Invest. 2017;6:1. doi: 10.21270/archi.v6i0.2255.

17.Momesso GAC, Colete JZ, Ervolino ACS, Hassumi JS, Puttini IO, Polo TOB, Faverani LP, Okamoto R. Tratamento com ranelato de estrôncio melhora atividade celular e microarquitetura óssea alveolar em ratas osteopênicas. Arch Health Invest. 2017;6:1. doi: 10.21270/archi.v6i0.2091.

18. Borges APB, Rezende CMF, Ribeiro MFB, Melo EG, Nóbrega NPI. Hidroxiapatita sintética como substituto ósseo em defeito experimental provocado no terço proximal da tíbia em cão: aspectos à microscopia eletrônica de transmissão. Arq Bras Med Vet Zootec. 2000;52:616-20. doi: 10.1590/ S0102-09352000000600011.

19.Figueiredo AS. Comparação entre hidroxiapatita porosa de coral e o enxerto ósseo autógeno em coelhos. Acta Cir Bras. 1997;12:84-8. doi: 10.1590/S010286502001000300009.

20.Duarte TS, Borges APB, Lavor MSL, Filgueiras $R$, Tsiomis AC, Fófano G, Odenthal ME, Pontesl KCS.. Osteointegração da hidroxiapatita sintética no processo alveolar da mandíbula de cães: aspectos clínicos e radiográficos. Arq Bras Med Vet Zootec. 2007;59:114-8. doi: 10.1590/S0102-09352007000100019.

21. Resende AC, Cunha LR, Saska S, BalducciRoslindo E, Minarelli-Gaspar AM. Análise biológica da hidroxiapatita após implantação em tíbias de ratos. Rev Bras Ortop. 2006;41:132-6.

\section{Acknowledgement}

To Instituto de Química, UFMS.

\section{Correspondence:}

landara Schettert Silva

Laboratório de Modelos Experimentais de Doença, UFMS

Avenida Senador Filinto Muller, s/n - Cidade Universitária

79070-900 Campo Grande - MS Brasil

Tel.: (55 67)3345-7234 / 99982-8635

ian.da.ra@hotmail.com

Received: May 16, 2018

Review: July 13, 2018

Accepted: Aug 18, 2018
Conflict of interest: none

Financial sources: CAPES, FINEP, FAPEC, and FUNDECT

${ }^{1}$ Research performed at Laboratory of Experimental Models of Disease, Universidade Federal do Mato Grosso do Sul (UFMS), Campo Grande-MS, Brazil. Part of PhD degree thesis, Postgraduate Program in Health and Development of the Center-West Region. Tutor: Iandara Schettert Silva. 